\title{
Seasonal variability of measured ozone production efficiencies in the lower free troposphere of Central Europe
}

\author{
P. Zanis ${ }^{1,2}$, A. Ganser ${ }^{3}$, C. Zellweger ${ }^{4}$, S. Henne ${ }^{4}$, M. Steinbacher ${ }^{4}$, and J. Staehelin ${ }^{3}$ \\ ${ }^{1}$ Research Centre for Atmospheric Physics and Climatology, Academy of Athens, Athens, Greece \\ ${ }^{2}$ Department of Meteorology and Climatology, School of Geology, Aristotle University of Thessaloniki, Greece \\ ${ }^{3}$ Institute for Atmospheric and Climate Science, ETH Zurich, Switzerland \\ ${ }^{4}$ Swiss Federal Institute for Materials Science and Technology (Empa), Laboratory for Air Pollution/Environmental \\ Technology, 8600 Dübendorf, Switzerland
}

Received: 9 June 2006 - Published in Atmos. Chem. Phys. Discuss.: 26 September 2006

Revised: 19 December 2006 - Accepted: 20 December 2006 - Published: 16 January 2007

\begin{abstract}
In this study we present the seasonal variability of ozone production efficiencies $\left(E_{N}\right)$, defined as the net number of ozone molecules produced per molecule of nitrogen oxides (nitrogen oxide $(\mathrm{NO})+$ nitrogen dioxide $\left.\left(\mathrm{NO}_{2}\right)=\mathrm{NO}_{\mathrm{x}}\right)$ oxidized to $\mathrm{NO}_{\mathrm{z}}$ (total reactive nitrogen $\left.\left(\mathrm{NO}_{\mathrm{y}}\right)-\mathrm{NO}_{\mathrm{x}}\right)$ determined from field measurements of a seven-year period (1998-2004) at the Swiss high-alpine research station Jungfraujoch (JFJ), $3580 \mathrm{~m}$ a.s.l. This dataset is a unique long-term data series of nitrogen levels in the free troposphere over Central Europe and hence it offers an excellent opportunity to perform such an analysis and provide further evidence to the photochemical origin of the ozone spring maximum at locations of the northern hemisphere distant from nearby pollution sources. Experimentally derived daily $E_{N}$ values have been selected for 571 days out of the 2557 days from 1998 to 2004, from which an average ozone production efficiency of $18.8 \pm 1.3$ molecules of $\mathrm{O}_{3}$ produced per molecule of $\mathrm{NO}_{\mathrm{x}}$ oxidized was calculated. This value indicates the great potential and importance of photochemical ozone production in the free troposphere. The monthly means of experimentally derived daily $E_{N}$ values show a seasonal variation with lower values from May to August, which can be probably attributed to more efficient vertical transport of polluted air masses from the atmospheric boundary layer up to JFJ. In agreement, theoretically derived monthly $E_{N}$ values show similar seasonal variation. The ratio $\mathrm{NO}_{\mathrm{y}} / \mathrm{CO}$, a parameter to assess the aging process that has occurred in an air parcel, was used as a criterion to disaggregate the 571 selected days between undisturbed and disturbed free tropospheric (FT). The monthly means of experimentally derived $E_{N}$ values for the undisturbed FT conditions show a distinct seasonal cycle with higher values in the cold season from
\end{abstract}

Correspondence to: P. Zanis

(pzanis@geol.uoa.gr)
November to April. The $E_{N}$ values for undisturbed FT conditions are particularly higher than the respective monthly $E_{N}$ values for disturbed FT conditions from February to October. It should be noted that the monthly $E_{N}$ values of $\operatorname{March}\left(E_{N}=35.8\right)$ and April $\left(E_{N}=34.9\right)$ are among the highest values throughout the year for undisturbed FT conditions at JFJ. These results highlight the key and possibly the dominant role for photochemistry in the observed build-up of tropospheric ozone in the winter-spring transition period.

\section{Introduction}

Over the last couple of decades it has become apparent that the measured annual cycle of ozone in certain locations of the northern hemisphere, distant from nearby pollution sources, shows a distinct maximum during spring. The magnitude of this maximum also seems to have increased with time (Monks, 2000). There has been much debate as to the origins of this phenomenon and on the relative contribution from photochemistry and stratospheric intrusions (Davies and Schuepbach, 1994; Stohl et al., 2003 and references therein). Nowadays, there is broad agreement that photochemistry is the major contributor to the observed background ozone levels in the troposphere (Penkett, 1988; Crutzen et al., 1999; Lelieveld and Dentener, 2000). According to the existing photochemical theory the relative importance of ozone production and loss processes in the remote troposphere is highly sensitive to competition between reaction of peroxy radicals with $\mathrm{NO}$ and cross- or selfreactions of the peroxy radicals, hence the local $\mathrm{NO}_{\mathrm{x}}$ and peroxy radical concentrations (e.g. Crutzen, 1988). At very low $\mathrm{NO}_{\mathrm{x}}$ concentrations ("clean" atmosphere) the conditions tend towards net ozone destruction due to $\mathrm{O}_{3}$ photolysis by

Published by Copernicus GmbH on behalf of the European Geosciences Union. 
near-ultraviolet light and due to reactions of $\mathrm{O}_{3}$, with $\mathrm{HO}_{2}$ and $\mathrm{OH}$, whereas when $\mathrm{NO}_{\mathrm{x}}$ is larger than around 50 pptv the tendency is to have net ozone production as oxidation of $\mathrm{NO}$ to $\mathrm{NO}_{2}$ by peroxy radicals dominates over the ozone loss processes (Crutzen, 1988; Penkett, 1988). This theory has been subject to intense investigation due to the observed ozone increase in the troposphere of the Northern Hemisphere over the last century as a result of increased anthropogenic emissions of ozone precursors (Volz-Thomas and Kley, 1988; Staehelin et al., 1994). In contrast, there is still no overarching consensus as to the mechanisms that lead to the formation of the spring ozone maximum, although a number of chemical theories were developed to explain the observed spring ozone maximum in the free troposphere (FT) of the Northern mid-latitudes (Penkett and Brice, 1986; Liu et al., 1987; Yienger et al., 1999; Monks, 2000).

Ozone in the remote free troposphere has a longer lifetime, which enables transport from regional to hemispheric scale and hence proportionally greater influence on climate than ozone near the surface (Lacis et al., 1990). Therefore, measurements in the free troposphere of the relevant trace gases such as $\mathrm{NO}_{\mathrm{x}}, \mathrm{NO}_{\mathrm{y}}, \mathrm{CO}, \mathrm{CH}_{4}$, VOCs and $\mathrm{H}_{2} \mathrm{O}$ that control the ozone abundances are essential for our understanding. It should be noted that such measurements are sparse compared to boundary layer data (Zellweger et al., 2003). Nitrogen oxides $\left(\mathrm{NO}_{\mathrm{x}}=\mathrm{NO}+\mathrm{NO}_{2}\right)$ are the limiting precursors for $\mathrm{O}_{3}$ production throughout most of the troposphere, and also directly influence the abundance of the hydroxyl radical concentration in the troposphere (e.g. Crutzen, 1988). Emissions of reactive nitrogen species occur primarily as $\mathrm{NO}$, followed by oxidation to $\mathrm{NO}_{2}$. Reactive nitrogen $\left(\mathrm{NO}_{\mathrm{y}}\right)$ is defined as the sum of $\mathrm{NO}_{\mathrm{x}}$ and its atmospheric oxidation products $\left(\mathrm{NO}_{\mathrm{z}}\right)$ including $\mathrm{N}$-containing particulates. The lifetime of $\mathrm{NO}_{\mathrm{x}}$ before photochemical conversion to $\mathrm{NO}_{\mathrm{z}}$ is less than a day in summer at mid-latitudes (Logan, 1983). $\mathrm{NO}_{\mathrm{z}}$ comprises mostly peroxyacetylnitrate (PAN) and nitric acid $\left(\mathrm{HNO}_{3}\right)$, along with $\mathrm{HNO}_{4}, \mathrm{~N}_{2} \mathrm{O}_{5}, \mathrm{NO}_{3}$ and other PAN homologues (PANs) and organic nitrates (Emmons et al., 1997). The relative abundance of the components of $\mathrm{NO}_{\mathrm{y}}$ varies significantly. For instance, $\mathrm{NO}_{2}$ is often dominant close to sources, while PAN tends to be the most abundant constituent in regionally polluted air masses where there is more active organic photochemistry and inorganic nitrates are most abundant in more remote areas of the troposphere (Zellweger et al., 2003).

A common index to estimate the ozone production in polluted areas as well as the clean free troposphere, is the ratio $\Delta \mathrm{O}_{3} / \Delta \mathrm{NO}_{\mathrm{z}}$, where $\mathrm{NO}_{\mathrm{z}}=\left(\mathrm{NO}_{\mathrm{y}}-\mathrm{NO}_{\mathrm{x}}\right)$ is the sum of $\mathrm{NO}_{\mathrm{x}}$ oxidation products. This index, known as the ozone production efficiency $\left(E_{N}\right)$, describes the number of $\mathrm{O}_{3}$ molecules chemically produced per molecule of $\mathrm{NO}_{\mathrm{x}}$ oxidized to $\mathrm{NO}_{\mathrm{z}}$ (Liu et al., 1987) and has been estimated from $\Delta \mathrm{O}_{3} / \Delta\left(\mathrm{NO}_{z}\right)$ ratios (Sillman et al., 1990; Trainer et al., 1993; Olszyna et al., 1994; Carpenter et al., 2000; Rickard et al., 2002, and references therein). Values of $E_{N}$ can be estimated from the slope of $\mathrm{O}_{3}$ versus $\mathrm{NO}_{\mathrm{z}}$ plots, whilst the ordinate intercepts of such plots have been interpreted as the "background" level of ozone. Estimates of the amount of ozone formed in a particular region can then be deduced from $E_{N}$ and known $\mathrm{NO}_{\mathrm{x}}$ emissions (Liu et al., 1987). $E_{N}$ depends on the $\mathrm{NMHC} / \mathrm{NO}_{\mathrm{x}}$ ratio as well as UV radiation, water vapour, and the ozone concentration itself. However, at $\mathrm{NO}_{\mathrm{x}}$ values less than a few parts per billion by volume, $\mathrm{O}_{3}$ formation is $\mathrm{NO}_{\mathrm{x}}$ limited (Liu et al., 1987) and therefore independent of hydrocarbon concentrations. The ozone production efficiency decreases when $\mathrm{NO}_{\mathrm{x}}$ mixing ratios reach higher values than approximately 500 pptv (Liu et al., 1987).

Generally, $\Delta \mathrm{O}_{3} / \Delta \mathrm{NO}_{\mathrm{z}}$ provides an upper limit for $E_{N}$ because $\mathrm{HNO}_{3}$ (one of the major contributors to $\mathrm{NO}_{z}$ ) is wet and dry deposited more rapidly than $\mathrm{O}_{3}$, while another limitation is the mixing of different air masses before arriving at the measuring site (Nunnermacker et al., 1998). Several factors can reduce the calculated $E_{N}$ value for FT air. For example, mixing with boundary layer air will decrease $\mathrm{O}_{3}$ and increase $\mathrm{NO}_{\mathrm{x}}$ and $\mathrm{NO}_{\mathrm{y}}$ mixing ratios, which results in lower $E_{N}$ values. PAN formation may also reduce $E_{N}$ values. Simulations of an air mass that was initialized with a mix of boundary layer and FT air at the altitude of the JFJ under summer time conditions, showed that $\mathrm{NO}_{\mathrm{x}}$ re-formation from PAN is the main source of $\mathrm{NO}_{\mathrm{x}}$ in the FT, even if an air mass remains at constant altitude (Henne et al., 2005b). Hence $E_{N}$ values at JFJ during summer time can be clearly affected by PAN formation. However, PAN decomposition is temperature dependent and hence seasonally dependent. For example during FREETEX ' 98 in early spring, it was shown that PAN decomposition did not contribute to $\mathrm{NO}_{\mathrm{x}}$ at $\mathrm{JFJ}$, as well as that PAN formation has minimal effect on $E_{N}$ values at JFJ (Carpenter et al., 2000). Instead, oxidation of $\mathrm{NO}_{\mathrm{x}}$ to PNA $\left(\mathrm{HO}_{2} \mathrm{NO}_{2}\right)$ may result in reducing the derived $E_{N}$ values during spring at JFJ (Carpenter et al., 2000). PNA formation usually is not an important process in the surface layer because it rapidly thermally decomposes. However, the lifetime of PNA at $-10^{\circ} \mathrm{C}$ is sufficient to allow the build-up of its daytime concentration to tens of parts per trillion by volume. During summer JFJ conditions, PNA does not play a significant role, since temperatures are about $0^{\circ} \mathrm{C}$ (Henne et al., 2005b). Furthermore, $\mathrm{HNO}_{3}$ scavenging is slow in the upper troposphere, so that $\Delta \mathrm{O}_{3} / \Delta \mathrm{NO}_{\mathrm{z}}$ should provide a rather good estimate of the true ozone production potential in the FT.

$E_{N}$ has been extensively investigated in recent years by researchers in the United States and Canada, but fewer studies have been carried out in Europe. Furthermore, few studies exist referring to $E_{N}$ determinations in the FT, which are mainly based on aircraft measurements in air masses transported downwind of pollution sources, and even fewer on the seasonal variability of $E_{N}$. An overview of previous $E_{N}$ determinations can be found in Rickard et al. (2002). As far as it concerns previous published work on the seasonality of $E_{N}$, there is sparseness of detailed studies. Based 
on box model calculations for sea level mid-latitudes Liu et al. (1987) found similar $E_{N}$ values for summer and winter above approximately $100 \mathrm{pptv}$ of $\mathrm{NO}_{\mathrm{x}}$. Hirsch et al. (1996) showed from 4-year measurements at a rural and forested site at Harvard Forest, Massachusetts, that $E_{N}$ increases from 4 in May to 8 in June-July and gradually decreases back to 4 by early October, attributing this seasonal trend to onset of biogenic emission of isoprene. The variation of $E_{N}$ with $\mathrm{NO}_{\mathrm{x}}$ as measured during three intensive field campaigns at two European coastal sites (Mace Head, Ireland and Weybourne, UK) suggests that ozone production efficiency is relatively insensitive to both geographical location and season (Rickard et al., 2002).

In this study we present the seasonal variability of ozone productions efficiencies $\left(E_{N}\right)$, which have been calculated from observed $\Delta \mathrm{O}_{3} / \Delta \mathrm{NO}_{\mathrm{z}}$ ratios for disturbed and undisturbed FT conditions based on continuous measurements of $\mathrm{NO}, \mathrm{NO}_{2}, \mathrm{NO}_{\mathrm{y}}, \mathrm{O}_{3}$ and $\mathrm{CO}$ carried out regularly for a sevenyear period (1998-2004) at the Swiss high-alpine research station Jungfraujoch (JFJ), $3580 \mathrm{~m}$ a.s.l.

\section{Data and methods}

\subsection{Site description and characteristics}

The Jungfraujoch (JFJ) Observatory $(7.98 \mathrm{E} / 46.55 \mathrm{~N})$ is located in the Swiss Alps, on a ridge extending from southwest to north-east, at an elevation of $3580 \mathrm{~m}$ a.s.l. To the north, the slope drops steeply down to $2000 \mathrm{~m}$ in a horizontal distance of $2-3 \mathrm{~km}$. The great Aletsch glacier with a length of $22 \mathrm{~km}$ lies to the south of this rocky ridge. JFJ is located, in winter and often in spring and autumn, in the lower FT, whereas there is clear influence from the planetary boundary layer (PBL) at least during daytime in summer when convective activity is enhanced (Baltensperger et al., 1997; Lugauer et al., 1998; DeWekker et al., 2004). Henne et al. (2005a) quantified the amount of ABL air in the lee of the Alps to be about $25 \%$ at $3500 \mathrm{~m}$ MSL for fair weather days during the warm season which can be seen as an upper limit for JFJ, being located in the center of the Alps. Hence, chemical and meteorological criteria are essential to distinguish between free tropospheric conditions and air masses disturbed by pollution sources (Brönnimann, 1999; Lugauer et al., 2000; Nyeki et al., 2000; Zellweger et al., 2000, 2003; Carpenter et al., 2000; Forrer et al., 2000; Schuepbach et al., 2001; DeWekker et al., 2004; Henne et al., 2004).

\subsection{Data and filtering}

Because the instrumental details have already been described elsewhere (Zellweger et al., 2000) only a brief summary of experimental aspects is presented here. Total $\mathrm{NO}_{\mathrm{y}}$ measurements commenced in March 1997 at the JFJ, while the measurements of $\mathrm{NO}$ and $\mathrm{NO}_{2}$ started in June 1991. NO,
$\mathrm{NO}_{\mathrm{x}}$ and $\mathrm{NO}_{\mathrm{y}}$ were measured with a commercially available instrument (CraNOx, Ecophysics) using two chemiluminescence detectors (CLD $770 \mathrm{AL}$ pptv) with temperaturecontrolled reaction chambers. $\mathrm{NO}_{\mathrm{x}}$ was measured as $\mathrm{NO}$ after photolytic conversion (PLC 760). $\mathrm{NO}_{y}$ species were converted on a heated gold catalyst $\left(300{ }^{\circ} \mathrm{C}\right)$ with $2 \% \mathrm{CO}$ (99.997\%, Messer-Griesheim $\mathrm{GmbH})$ as a reducing agent. The instrumental detection limit for $\mathrm{NO}, \mathrm{NO}_{2}$ and $\mathrm{NO}_{\mathrm{y}}$ was 50 pptv for $2 \mathrm{~min}$ and $20 \mathrm{pptv}$ for $30 \mathrm{~min}$ average values, respectively. Overall uncertainties in the measurements were estimated to be $\pm 5 \%$ for $\mathrm{NO}, \pm 10 \%$ for $\mathrm{NO}_{2}$ and $\pm 9 \%$ for $\mathrm{NO}_{\mathrm{y}}$ at ambient levels of $500 \mathrm{pptv}(1 \sigma)$. During the FREETEX 1998 field campaign $\mathrm{NO}_{\mathrm{x}}$ and $\mathrm{NO}_{\mathrm{y}}$ were measured independently by University of East Anglia (UEA) using a custom-built Cranox system and the agreement between the UEA and EMPA $\mathrm{NO}_{\mathrm{x}}$ and $\mathrm{NO}_{\mathrm{y}}$ data was within about 10\% (Carpenter et al., 2000; Zellweger et al., 2000). Both $\mathrm{CO}$ and $\mathrm{O}_{3}$ were continuously monitored with commercially available instruments by the Swiss National Air Pollution Monitoring Network (NABEL) (APMA-360, Horiba, for CO; Thermo Environmental Instruments, Model 49C, for $\mathrm{O}_{3}$ ). The detection limit was $30 \mathrm{ppbv}$ for $\mathrm{CO}$ and $0.5 \mathrm{ppbv}$ for $\mathrm{O}_{3}$ (30 min average). More detailed information including measurement uncertainties and the calibration procedure can be found in Zellweger et al. (2000). Finally the meteorological measurements including wind speed and direction, relative humidity, temperature, global radiation and atmospheric pressure at JFJ were provided by MeteoSwiss, Zürich.

The use of filters at the JFJ (and other measurement sites) is crucial for the interpretation of data from such measurement sites. Carpenter et al. (2000) and Zanis et al. (2000a) used filters based on chemical parameters to select clean free tropospheric days during the FREETEX '98 campaign, while Schuepbach et al. (2001) performed a filtering analysis for the long-term ozone record at JFJ using the wind sector and speed in association with a night-time window as filters. There are also a number of studies in which filters based mainly on meteorological parameters were used to discriminate between undisturbed (i.e. clean) and disturbed (i.e. influenced by regional pollution sources) free tropospheric conditions at the JFJ (Lugauer et al., 1998, 2000; Forrer et al., 2000; Zellweger et al., 2003; Henne et al., 2005a; Henne et al., 2005b). Zellweger et al. (2003) suggested that an alternative parameter to assess the aging process that has occurred in an air parcel is the $\mathrm{NO}_{\mathrm{y}} / \mathrm{CO}$ ratio, which accounts for both deposition and dilution effects. The relationship between $\mathrm{CO}$ and $\mathrm{NO}_{\mathrm{y}}$ was previously used to assess anthropogenic input to air masses by Parrish et al. (1991). Close to anthropogenic sources, the $\mathrm{NO}_{\mathrm{y}} / \mathrm{CO}$ ratio averages $\sim 0.1$, whereas values of $\sim 0.005$ are observed in the upper troposphere (Jaeglé et al., 1998). This is in line with recent findings of Stohl et al. (2002) where the original emission ratio between $\mathrm{NO}_{\mathrm{y}}$ and $\mathrm{CO}$ was assumed to be 0.16 . This ratio dropped to values below 0.01 for air masses older than four days in the continental outflow region of North America. However, it 
should be noted that the $\mathrm{NO}_{\mathrm{y}} / \mathrm{CO}$ ratio also shows a seasonal variation, with lower values during the winter months due to a longer lifetime of $\mathrm{CO}$.

Zellweger et al. (2003) showed from $\mathrm{NO}_{y}$ and $\mathrm{CO}$ measurements at JFJ from April 1997 to March 1999 that undisturbed FT conditions are always accompanied by the lowest $\mathrm{NO}_{\mathrm{y}} / \mathrm{CO}$ ratios, indicating advanced aging of these air masses. The $\mathrm{NO}_{\mathrm{y}} / \mathrm{CO}$ filter works well for excluding days affected by thermally induced transport up to JFJ, because the vertical gradient of $\mathrm{NO}_{\mathrm{y}}$ is usually much more pronounced compared to $\mathrm{CO}$ in a continental location. Other upslope transport processes which can influence the JFJ site include Foehn (both north and south), and synoptical lifting. These processes are often associated with precipitation, which potentially scavenges some $\mathrm{NO}_{\mathrm{y}}$ species $\left(\mathrm{HNO}_{3}\right.$, particulate nitrate). This scavenging will lower the $\mathrm{NO}_{\mathrm{y}} / \mathrm{CO}$ ratio, and it could then be misinterpreted as free tropospheric air masses. However, due to its location in a continental area, the pronounced vertical gradients of $\mathrm{NO}_{\mathrm{y}}$ species favor higher $\mathrm{NO}_{\mathrm{y}} / \mathrm{CO}$ ratios even during periods with potential precipitation scavenging. For example, south Foehn events during spring and autumn were always associated with high $\mathrm{NO}_{\mathrm{y}} / \mathrm{CO}$ ratios (Zellweger et al., 2003), despite precipitation loss of $\mathrm{NO}_{\mathrm{y}}$. Furthermore, cloud processing itself without the presence of precipitation should not influence the $\mathrm{NO}_{\mathrm{y}} / \mathrm{CO}$ ratio as it will maybe reduce the $\mathrm{HNO}_{3}$, but not the total nitrate content. Particulate nitrate is also measured as $\mathrm{NO}_{\mathrm{y}}$ with the experimental setup at JFJ. This ratio is therefore viewed as suitable method to distinguish between disturbed and undisturbed FT conditions at the JFJ and hence is used in the current analysis.

In order to confirm the validity of the $\mathrm{NO}_{\mathrm{y}} / \mathrm{CO}$ filter for selecting undisturbed FT conditions in our study we used other commonly used meteorological indices for filtering such as the weather type of the Alpine Weather Statistics (AWS) (Schüepp, 1979; Wanner et al., 1998), the "sun" day index (SND) and the "radiation" day index (RAD) to identify fair weather conditions that favour thermal convection (Henne et al., 2005a) as well as the indication for South or North Foehn events (Forrer et al., 2000). The aim was to crosscheck the distribution of AWS, SND and RAD indices for selected undisturbed FT days accompanied by the lowest quartile $\mathrm{NO}_{\mathrm{y}} / \mathrm{CO}$ ratio values ( $<1$ st quartile).

According to Schüepp's weather classification in AWS a region of $444 \mathrm{~km}$ in diameter over the central Alps is considered and each day is attributed to a specific synoptic weather type based on a number of meteorological parameters including the surface pressure and the $500 \mathrm{hPa}$ heights (Schüepp, 1979). There are 40 weather types in AWS which can be sorted out into three large categories (Convective, Advective and Mixed). The Convective category has three subcategories, anticyclonic (A), indifferent (I) and cyclonic (C), while Advective category has four sub-categories, West (W), North (N), East (E), and South (S).
The SND and RAD indices are based on data from the automated MeteoSwiss surface station network on both sides of the Alps covering the whole Swiss plateau in the west-east direction and the Ticino area south of the Alps (Henne et al., 2005a). If the total sunshine duration per day was larger than $9 \mathrm{~h}$ for at least $50 \%$ of the stations in the north and $50 \%$ of the stations in the south, a day was categorized as being a "sun day" (SND). If the total amount of incoming solar radiation per day to the earth's surface was larger than $19 \mathrm{MJ} \mathrm{m}^{-2}$ at more than $50 \%$ of the stations in the north and south, a day was categorized as being a "radiation day" (RAD). Atmospheric conditions on days selected by RAD and SND index can be seen as necessary conditions to create thermally induced up-slope flow. However, undisturbed FT conditions might still be present at high altitudes, if mixing and up-slope transport was limited to lower altitudes.

Concerning the relation between AWS classification and the selected undisturbed FT days accompanied by the lowest quartile $\mathrm{NO}_{\mathrm{y}} / \mathrm{CO}$ ratio values it was found that $33 \%$ of the days were Anticyclonic, 35\% were Indiferent, $26 \%$ were Advective (N,W,S,E), $4 \%$ were Mixed and only $2 \%$ were Cyclonic. As far as it concerns the SND and RAD criteria $22 \%$ of the selected days were classified as sun days and $27 \%$ as radiation days. Furthermore, only $13 \%$ of the selected undisturbed FT days (17 days) were fulfilling simultaneously the criteria of a sun day, radiation day and anticyclonic or indifferent day which are days that can be potentially affected by thermal convection. Among these 17 days, 14 days were during the warm period from May to September when thermally induced convective activity is enhanced at JFJ. These 14 days account for $19 \%$ of the selected days within the period from May to September. Hence the $\mathrm{NO}_{\mathrm{y}} / \mathrm{CO}$ filter worked relatively well in excluding days which have a high potential to be affected by thermal convection from ABL.

Finally out of the selected undisturbed FT days accompanied by the lowest quartile $\mathrm{NO}_{\mathrm{y}} / \mathrm{CO}$ ratio values only $5 \%$ can be potentially affected by Foehn events and only $2 \%$ by cyclonic synoptic systems which are weather conditions that favor precipitation. This implies the limited influence of precipitation on $E_{N}$ calculation for the selected undisturbed FT days.

\subsection{Observed and steady state calculations of $E_{N}$}

Using the whole dataset (1998-2004), ozone production efficiencies $\left(E_{N}\right)$ have been calculated on a daily basis for daytime periods. Specifically, $30 \mathrm{~min}$ averages of $\mathrm{O}_{3}$ and $\mathrm{NO}_{\mathrm{z}}$ values were used from $8 \mathrm{AM}$ to $8 \mathrm{PM}$ (UTC) to determine the slope of $\mathrm{O}_{3}$ versus $\mathrm{NO}_{\mathrm{z}}$ for each individual day from the 2557 days between 1998 and 2004. An example of the calculation of a daily $E_{N}$ value is illustrated in Fig. 1 for date 24/07/2003. This is a day with a low $E_{N}$ value of 5.9 as calculated from the slope of simple linear regression line (or 6.3 based on the organic correlation method that takes into account the uncertainties in both axes) which might be asso- 
ciated with transport of relatively freshly polluted air masses up to the JFJ. The calculated daily $E_{N}$ values were only used for the subsequent analyses if the following criteria were fulfilled. First, concurrent measurements of $\mathrm{O}_{3}, \mathrm{NO}_{\mathrm{x}}, \mathrm{NO}_{\mathrm{y}}$ and $\mathrm{CO}$ were available for the individual days. With this first criterion 2120 days were selected out of the 2557 days. Second, the correlation coefficient between $\mathrm{O}_{3}$ and $\mathrm{NO}_{\mathrm{z}}$ exceeded the value of +0.5 . With this second criterion 617 days were selected. Third, the regression coefficient $\Delta \mathrm{O}_{3} / \Delta \mathrm{NO}_{\mathrm{z}}$ of $\mathrm{O}_{3}$ versus $\mathrm{NO}_{\mathrm{z}}$, which corresponds to the $E_{N}$, was statistically significant at the $95 \%$ level. With this third criterion 598 days were selected. Finally, the calculated daily $E_{N}$ values, which were outside the range of the average of all daily $E_{N}$ values $\pm 2 \sigma$, were considered as outliers and have been excluded from further analysis. With the above criteria 571 out of 2557 days have been selected for further analysis from 1998 to 2004.

The selection criteria deduce $E_{N}$ values which are biased towards those conditions that give better than average regression fits thus eliminating days with low photochemical activity and days with net ozone loss. However, the fact that $75 \%$ of the days do not meet the above criteria does not necessarily imply that there is no ozone production for these days because possibly transport processes mask photochemistry. For example during winter when the ozone lifetime is longer compared to summer we have fewer days fulfilling the above criteria. Furthermore, there is a significant number of days (429) with negative correlation between $\mathrm{O}_{3}$ and $\mathrm{NO}_{\mathrm{z}}$ $(\rho<-0.5)$ which can be partly related to downward transport from the upper troposphere/lower stratosphere. Days with net ozone chemical loss cannot be disregarded as a possibility at JFJ especially when $\mathrm{NO}_{\mathrm{x}}$ levels are lower than about $50 \mathrm{pptv}$ but such days were rarely found. For example based on measurements of peroxy radicals and other relevant chemical species and photochemical parameters at JFJ, positive net ozone production rates were calculated in the vast majority of the days during FREETEX '98 (from mid-March to mid-April) ranging from around $0.1 \mathrm{ppbv} \mathrm{h}^{-1}$ on relatively clean days to more than $1 \mathrm{ppbv} \mathrm{h}^{-1}$ on relatively polluted days (Zanis et al., 2000a). Positive net ozone production rates were also calculated from observations during FREETEX '96 (mid-April to mid-May) and FREETEX '01 (midFebruary to mid-March) (Zanis et al., 2003).

Zanis et al. (2000b) have shown that for low and mid- $\mathrm{NO}_{\mathrm{x}}$ conditions typical for JFJ, the important peroxy/hydroxyl radical ratio can be expressed by an empirical equation, which takes account of radical recombination and interconversion through $\mathrm{O}_{3}$, as well as $\mathrm{NO}_{\mathrm{x}}$ processes, although it ignores NMHC chemistry:

$$
\begin{aligned}
& \frac{\left[\mathrm{HO}_{2}+\mathrm{CH}_{3} \mathrm{O}_{2}\right]}{[\mathrm{OH}]}= \\
& \frac{k_{\mathrm{OH}+\mathrm{CO}} \cdot[\mathrm{CO}]+k_{\mathrm{OH}+\mathrm{CH}_{4}} \cdot\left[\mathrm{CH}_{4}\right]+k_{\mathrm{OH}+\mathrm{O}_{3}} \cdot\left[\mathrm{O}_{3}\right]}{k_{\mathrm{HO}_{2}+\mathrm{NO}} \cdot[\mathrm{NO}]+k_{\mathrm{HO}_{2}+\mathrm{O}_{3}} \cdot\left[\mathrm{O}_{3}\right]+2 \cdot \sqrt{k^{\prime} \cdot k \cdot \mathrm{j}\left(\mathrm{O}^{1} \mathrm{D}\right) \cdot\left[\mathrm{O}_{3}\right]}}
\end{aligned}
$$

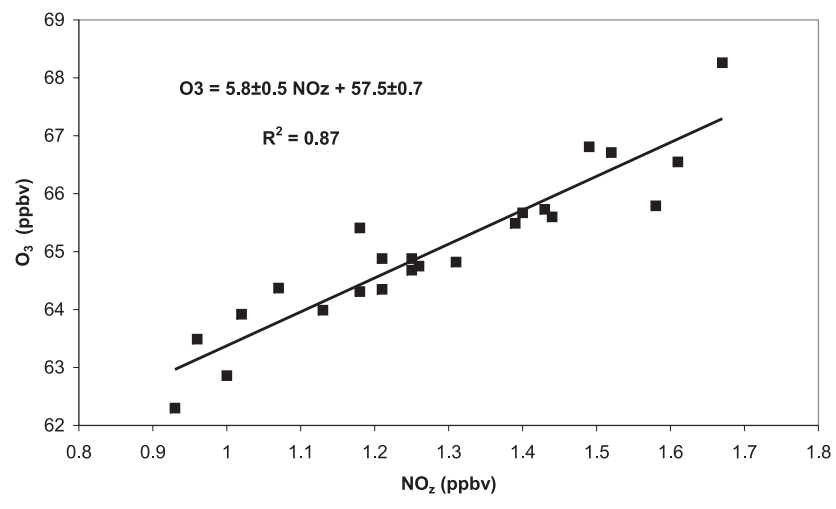

Fig. 1. Scatter plot of half-hourly averages of $\mathrm{O}_{3}$ versus $\mathrm{NO}_{Z}$ at JFJ from 8 AM to 8 PM (UTC) on 24/07/2003.

It has been shown that the ratio $\mathrm{HO}_{2}+\mathrm{CH}_{3} \mathrm{O}_{2} / \mathrm{OH}$, calculated with the empirical expression (1), approximates the ratio calculated by a $\mathrm{CO}-\mathrm{CH}_{4}$ photochemical box model very well for the whole range of $\mathrm{NO}$ concentrations (Zanis et al., $2000 \mathrm{~b})$. The required values of $\mathrm{O}_{3}, \mathrm{CO}, \mathrm{NO}, \mathrm{NO}_{2}$, temperature, $\mathrm{H}_{2} \mathrm{O}$, and pressure in Eq. (1) were based on the observations. All the necessary kinetic data for the calculation of the rate constants are based on Sander et al. (2003). A methane $\left(\mathrm{CH}_{4}\right)$ mixing ratio of $1800 \mathrm{ppbv}$ was assumed in Eq. (1). The ozone photolysis rate $\mathrm{j}\left(\mathrm{O}^{1} \mathrm{D}\right)$ for the 15 th of each month was calculated by the HARWELL radiative transfer model (Hough, 1988). The Harwell radiative transfer model has been adjusted for the conditions at the JFJ by setting the ground at $3 \mathrm{~km}$, and using a surface albedo of 0.65 . The coefficient $k^{\prime}$ is a composite rate constant made up from the individual rate constants of the self- and cross-reactions for $\mathrm{HO}_{2}$ and $\mathrm{CH}_{3} \mathrm{O}_{2}$ and $f$ is the proportion of $\mathrm{O}^{1} \mathrm{D}$ which reacts with water vapor. The moles of ozone produced from solely $\mathrm{CO}$ and $\mathrm{CH}_{4}$ chemistry $\left[\mathrm{PO}_{3}\right]$ per mole of $\mathrm{NO}_{\mathrm{x}}$ oxidized $\left[\mathrm{RNO}_{\mathrm{x}}\right]$ can thus be estimated by multiplying Eq. (1)

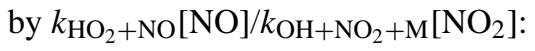

$$
\begin{aligned}
& \mathrm{E}_{\mathrm{N}}=\frac{\left[\mathrm{PO}_{3}\right]}{\left[\mathrm{RNO}_{\mathrm{x}}\right]}=\frac{k_{\mathrm{HO} 2+\mathrm{NO}} \cdot[\mathrm{NO}]}{k_{\mathrm{OH}+\mathrm{NO}_{2}+\mathrm{M}} \cdot\left[\mathrm{NO}_{2}\right]} . \\
& \frac{k_{\mathrm{OH}+\mathrm{CO}} \cdot[\mathrm{CO}]+k_{\mathrm{OH}+\mathrm{CH}_{4}} \cdot\left[\mathrm{CH}_{4}\right]+k_{\mathrm{OH}+\mathrm{O}_{3}} \cdot\left[\mathrm{O}_{3}\right]}{k_{\mathrm{HO}_{2}+\mathrm{NO}} \cdot[\mathrm{NO}]+k_{\mathrm{HO} 2+\mathrm{O}_{3}} \cdot\left[\mathrm{O}_{3}\right]+2 \cdot \sqrt{k^{\prime} \cdot \mathrm{f} \cdot \mathrm{j}\left(\mathrm{O}^{1} \mathrm{D}\right) \cdot\left[\mathrm{O}_{3}\right]}}
\end{aligned}
$$

Carpenter et al. (2000) have used Eq. (2) to calculate a $E_{N}$ value for typical mid- to low- $\mathrm{NO}_{\mathrm{x}}$ conditions often experienced at the JFJ research station, in free tropospheric air masses. It should be noted that Eq. (2) does not include the effects of PAN and PNA formation which may reduce $E_{N}$ values as discussed in Sect. 1. Sensitivity analysis of Eq. (2) for typical JFJ conditions throughout the year revealed that $E_{N}$ is mainly sensitive to $\mathrm{NO}$ and $\mathrm{NO}_{2}$. For example, $20 \%$ increase in $\mathrm{NO}_{2}, \mathrm{NO}, \mathrm{O}_{3}, \mathrm{CH}_{4}$, and $\mathrm{CO}$, result to percentage change for $E_{N}$ value of $-16 \%, 9 \%,-3.5 \%, 2.8 \%$, and $1 \%$, 


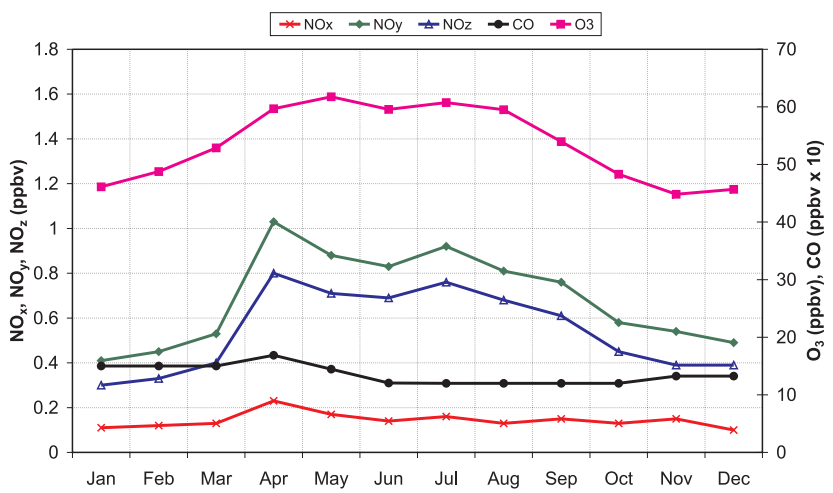

Fig. 2. Median monthly values of $\mathrm{NO}_{\mathrm{x}}, \mathrm{NO}_{\mathrm{y}}, \mathrm{NO}_{\mathrm{z}}, \mathrm{CO}$ and $\mathrm{O}_{3}$ at JFJ over the whole period between 1998 and 2004.

respectively, while $E_{N}$ is almost insensitive to $\mathrm{H}_{2} \mathrm{O}$, pressure and $\mathrm{j}\left(\mathrm{O}^{1} \mathrm{D}\right)$. We have also evaluated that an increase of $20 \%$ in temperature results to a percentage change of $E_{N}$ of $1 \%$ directly from Eq. (3) and 2-3\% through the temperature dependence of the $\mathrm{NO} / \mathrm{NO}_{2}$ ratio.

\section{Results and discussion}

3.1 An overview of the measurements at JFJ from 1998 to 2004

An overview of monthly median values of $\mathrm{NO}_{\mathrm{x}}, \mathrm{NO}_{\mathrm{y}}, \mathrm{NO}_{\mathrm{z}}$, $\mathrm{CO}$ and $\mathrm{O}_{3}$ over the whole period 1998-2004 without any filter is given in Fig. 2. The monthly medians in Fig. 2 were calculated from all data throughout a day but the result is similar if we use only the daytime data from $8 \mathrm{AM}$ to $8 \mathrm{PM}$. Generally, as it is shown in Fig. 2, $\mathrm{O}_{3}$ displays a broad springsummer maximum from April to August peaking in May. The broad spring-summer maximum at the JFJ has been previously reported by Schuepbach et al. (2001) while a similar seasonality has been also reported based on surface ozone measurements at Arosa, Switzerland (Staehelin et al., 1994) and on ozonesonde measurements in the lower FT at Payerne, Switzerland (Staehelin and Schmid, 1991). The May peak in $\mathrm{O}_{3}$ is evidenced in the monthly means of 5 individual years out of the 7 years of measurements from 1998 to 2004 while in 1999 there is an ozone peak in April and in 2003 there is an ozone peak in August (see Fig. 3). The ozone peak in August 2003 corresponds to the record-breaking heat wave affecting the European continent in summer 2003 (Schär et al., 2004; Ordonez et al., 2005). Higher CO mixing ratios are observed during the cold season from November to April due to the longer lifetime of $\mathrm{CO}$ (Fig. 2). Interestingly, $\mathrm{CO}$ consistently peaks in April for the whole period from 1998 to 2004 as illustrated in Fig. 3 although considering the lifetime of $\mathrm{CO}$ the maximum would rather be expected in mid-winter.

Concerning $\mathrm{NO}_{\mathrm{y}}$, higher concentrations were observed at the JFJ from April to August peaking in April (Fig. 2). This

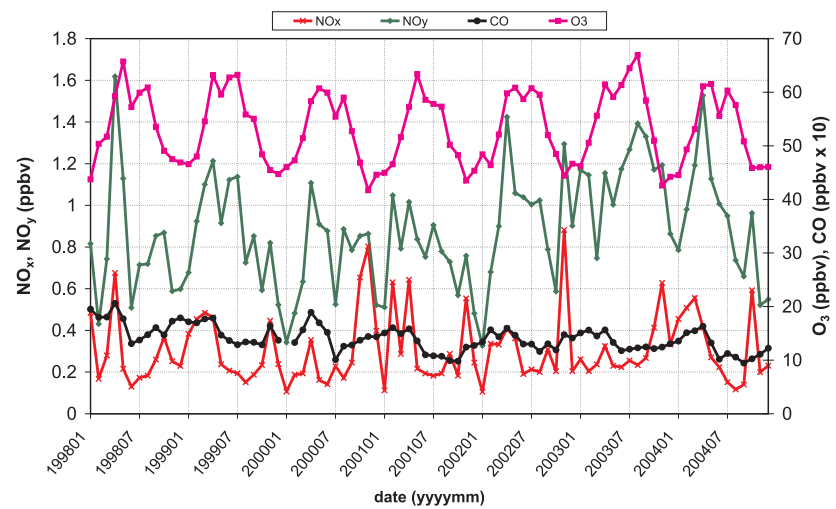

Fig. 3. Individual monthly mean values of $\mathrm{NO}_{\mathrm{x}}, \mathrm{NO}_{\mathrm{y}}, \mathrm{CO}$ and $\mathrm{O}_{3}$ at JFJ from 1998 to 2004.

April peak in $\mathrm{NO}_{\mathrm{y}}$ is observed in the monthly means of $5 \mathrm{in}-$ dividual years from the 7 years of measurements from 1998 to 2004 (Fig. 3). The $\mathrm{NO}_{\mathrm{y}}$ peak in August 2003 may be explained as for $\mathrm{O}_{3}$ by the heat wave affecting the European continent. Generally, the higher $\mathrm{NO}_{\mathrm{y}}$ concentrations during the warm season from late spring to early autumn were attributed to enhanced vertical transport processes during these seasons (Zellweger et al., 2000). The monthly $\mathrm{NO}_{z}$ concentrations show similar seasonal variability with $\mathrm{NO}_{\mathrm{y}}$ concentrations indicating the dominant role of $\mathrm{NO}_{z}$ in $\mathrm{NO}_{\mathrm{y}}$ partitioning. Concerning the $\mathrm{NO}_{\mathrm{y}}$ partitioning, Zellweger et al. (2003) showed that PAN was found to be the dominant $\mathrm{NO}_{\mathrm{y}}$ species during spring and summer, $\mathrm{NO}_{2}$ was most abundant during autumn and winter, whereas particulate nitrate was found to contribute significantly to total $\mathrm{NO}_{\mathrm{y}}$ during thermally induced vertical transport.

The monthly median $\mathrm{NO}_{\mathrm{x}}$ concentrations in Fig. 2 show a peak value in April but do not reveal a distinct seasonal pattern. This is possibly due to the opposite effect of two processes; the thermally induced vertical transport that peaks in summer and vents fresh pollution into the FT and the chemical lifetime of $\mathrm{NO}_{\mathrm{x}}$ that is significantly longer in winter (Liu et al., 1987). The monthly means of $\mathrm{NO}_{\mathrm{x}}$ concentrations for each individual year between 1998 and 2004 reveal primary and secondary peak concentrations in April and November for 5 years out of the 7 years of measurements while for the other two years peak concentrations are present in March and October. It should be noted that the monthly mean values of $\mathrm{NO}_{\mathrm{x}}$ and $\mathrm{NO}_{\mathrm{y}}$ were often found to be a factor of two or more higher than the corresponding median values due to the occurrence of relatively short episodes with high concentrations, which can be attributed to periods with transport of polluted air masses from source regions to the JFJ caused by various meteorological processes (Zellweger et al., 2000).

A striking feature, as inferred from Fig. 2 and Fig. 3, is the monthly peak values of $\mathrm{NO}_{\mathrm{y}}, \mathrm{NO}_{\mathrm{z}}$, and $\mathrm{NO}_{\mathrm{x}}$ in April, which is a consistent feature for most of the individual years between 1998 and 2004 in accordance with what it is also 


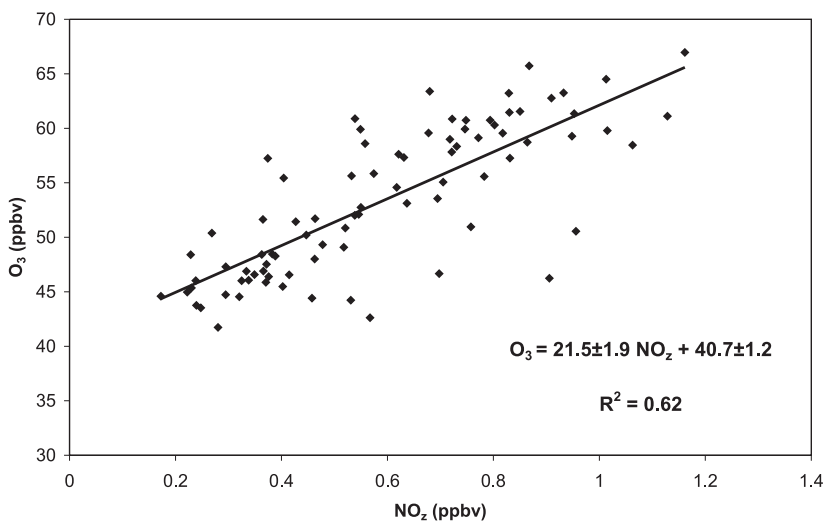

Fig. 4. Scatter plot of monthly means of $\mathrm{O}_{3}$ versus $\mathrm{NO}_{\mathrm{Z}}$ at JFJ from 1998 to 2004.

observed for CO. In contrast, the period when thermally induced vertical transport gets more efficient is the warm period from May to September with the highest potential in July and August (Lugauer et al., 1998; Henne et al., 2005a). This implies that presumably other transport processes of polluted air masses from regional to hemispheric scale can account for the April peak in $\mathrm{NO}_{\mathrm{y}}, \mathrm{NO}_{\mathrm{x}}$ and $\mathrm{CO}$ at JFJ in combination with the relatively longer chemical lifetime of these species in early spring compared to summer. The $\mathrm{NO}_{\mathrm{y}}$ data from 1996 to 2001 at Zugspitze (not shown here), Germany (World Data Centre for Greenhouse Gases; http://gaw.kishou.go.jp/wdcgg.html) also reveal a clear mean seasonal cycle with peak in April in agreement with JFJ confirming the theory of larger scale processes. In addition, Penkett and Brice (1986) based on the analysis of PAN measurements showed a large PAN increase in background Northern Hemisphere air during springtime and developed a theory to explain the observed spring ozone maximum in the FT since PAN is an excellent tracer of the photochemical activity. It should be also noted that the seasonal variation of the frequency of south Foehn events from April 1997 to March 1999 at JFJ shows a peak in April (Zellweger et al., 2003) while Campana et al. (2005) reported enhanced $\mathrm{O}_{3}$ and $\mathrm{NO}_{\mathrm{y}}$ levels at Arosa during south Foehn events in spring.

Figure 4 shows the monthly means of $\mathrm{O}_{3}$ versus $\mathrm{NO}_{\mathrm{z}}$ at JFJ from 1998 to 2004 . The explained variance is $62 \%$ while the regression coefficient $\Delta \mathrm{O}_{3} / \Delta \mathrm{NO}_{\mathrm{z}}$ from the scatter of $\mathrm{O}_{3}$ versus $\mathrm{NO}_{\mathrm{z}}$ is $21.5 \pm 1.9$. A prerequisite for the calculation of $E_{N}$ is to follow the same air mass from the source to the receptor. The estimate of $\Delta \mathrm{O}_{3} / \Delta \mathrm{NO}_{\mathrm{z}}$ from Fig. 4, although it assumes different air masses with different background ozone mixing ratios throughout the year, reflects the annual average ozone production efficiency at JFJ and indicates the great potential and importance of photochemical ozone production in the FT. The intercept reflecting the present time background ozone on which photochemistry builds on throughout the year is estimated to be $40.7 \pm 1.2 \mathrm{ppbv}$ and

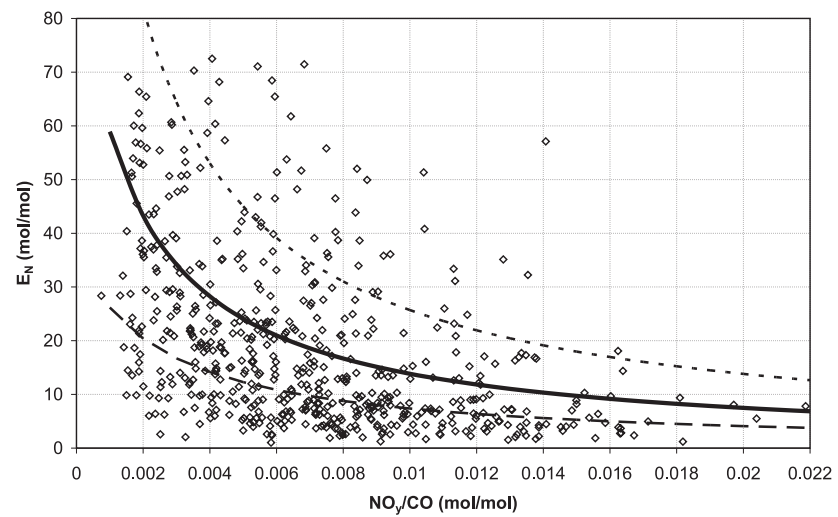

Fig. 5. Scatter plot of the experimentally derived daily values of $E_{N}\left(\Delta \mathrm{O}_{3} / \Delta \mathrm{NO}_{z}\right)$ versus the respective daily values of the ratio $\mathrm{NO}_{\mathrm{y}} / \mathrm{CO}$ for the 571 selected days between 1998 and 2004 following the selection criteria described in Section 2.3. The black solid line denotes a theoretical curve of $E_{N}$ values calculated by the steady state Eq. (2) for varying $\mathrm{NO}_{\mathrm{y}} / \mathrm{CO}$ by setting the levels of $\mathrm{O}_{3}$ (median $54.6 \mathrm{ppbv}$ ), $\mathrm{CO}$ (median $140 \mathrm{ppbv}$ ), $\mathrm{H}_{2} \mathrm{O}$ (median $3.0 \mathrm{~g} / \mathrm{kg}$ ), temperature (median $-4.8^{\circ} \mathrm{C}$ ), pressure (median $657.1 \mathrm{hPa}$ ), $\mathrm{NO} / \mathrm{NO}_{\mathrm{x}}$ (median 0.20) and $\mathrm{NO}_{\mathrm{x}} / \mathrm{NO}_{y}$ (median 0.20) to their median values from the 571 days selected days. The dotted and dashed lines denote the respective theoretical $E_{N}$ values by setting the ratio $\mathrm{NO}_{\mathrm{x}} / \mathrm{NO}_{y}$ to their 1 st quartile value $(0.13)$ and $3 \mathrm{rd}$ quartile value $(0.31)$ from the 571 selected days (instead of their median values) while keeping all the other variables $\left(\mathrm{O}_{3}, \mathrm{CO}, \mathrm{H}_{2} \mathrm{O}\right.$, temperature, pressure) constant to their median values.

compares well to winter ozone concentrations at JFJ.

\subsection{Selected daily values of $E_{N}$}

The daily $E_{N}$ values derived from the slope $\left(\Delta \mathrm{O}_{3} / \Delta \mathrm{NO}_{\mathrm{z}}\right)$ for 571 days, selected out of the 2557 days from 1998 to 2004 following the selection criteria described in Sect. 2.3 give an average ozone production efficiency of $18.8 \pm 1.3$ (the error bar denotes the $95 \%$ confidence interval), which is comparable with the $E_{N}$ value of $21.5 \pm 1.9$ derived from the monthly means of $\mathrm{O}_{3}$ and $\mathrm{NO}_{\mathrm{z}}$ at JFJ from 1998 to 2004 shown in Fig. 4. However, Fig. 5 shows that there is large scatter of these experimentally derived daily $E_{N}$ values ranging from 1 to 72 molecules of $\mathrm{O}_{3}$ produced per molecule of $\mathrm{NO}_{\mathrm{x}}$ oxidized to $\mathrm{NO}_{z}$, which shows the influence of both free tropospheric and polluted air masses with different chemical composition and aging at the JFJ. In previous published work, Carpenter et al. (2000), based on a 5-week observation of $\mathrm{O}_{3} / \mathrm{NO}_{\mathrm{Z}}$ ratios during FREETEX ' 98 at Jungfraujoch in March and April, derived $E_{N}$ values of about 20 to 30 molecules of $\mathrm{O}_{3}$ produced per $\mathrm{NO}_{2}$ molecule oxidised in free tropospheric conditions while a $E_{N}$ value of about 4 was calculated in photochemically aged air from South Europe. Prévôt et al. (1997), based on aircraft measurements in the Swiss Alps as part of the POLLUMET study, calculated $E_{N}$ values of 13.6 under $\mathrm{NO}_{\mathrm{x}}$-limited condtions and of 4.2 


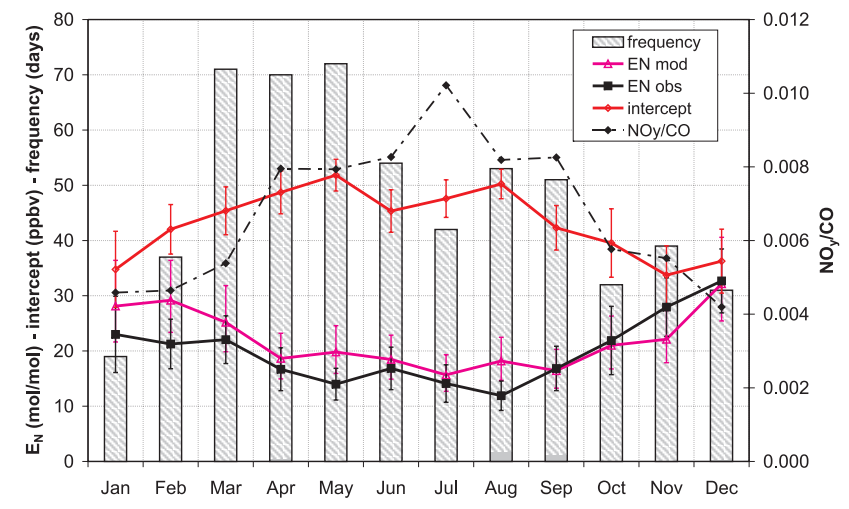

Fig. 6. Seasonal variation of monthly means of experimentally derived $E_{N}\left(\Delta \mathrm{O}_{3} / \Delta \mathrm{NO}_{z}\right)$ values and of the intercept along with the monthly means of the respective $\mathrm{NO}_{\mathrm{y}} / \mathrm{CO}$ values. The frequency of the selected days per month, for which daily values of $E_{N}$ were experimentally derived following the selection criteria described in Sect. 2.3, are also superimposed with grey column bars. Theoretically derived (modelled) monthly $E_{N}$ values are also demonstrated with open pink triangles. The theoretical $E_{N}$ values were calculated from the steady state Eq. (2) by setting the levels of $\mathrm{NO}, \mathrm{NO}_{2}, \mathrm{O}_{3}$, $\mathrm{CO}, \mathrm{H}_{2} \mathrm{O}$, temperature and pressure to their median monthly values from the 571 days selected days between 1998 and 2004 following the selection criteria described in Sect. 2.3. The error bars on the monthly means of experimentally derived $E_{N}$ denote their $95 \%$ confidence interval. The error bars on the theoretical $E_{N}$ values denote their $10 \%$ sensitivity to the median value.

close to the $\mathrm{NO}_{\mathrm{x}} / \mathrm{VOC}$ limiting transition point. Thielmann et al. (2002) based on field measurements in the Italian Po basin derived $E_{N}$ values at a rural station as low as 2.5 for air masses advected from Milan, Italy. Chin at al. (1994) reported a mean $\mathrm{O}_{3}$ production efficiency in the U.S. boundary layer of 5.5 with values being more than 2 times higher in the western United States (9.1) compared to the east (4.2) due to lower $\mathrm{NO}_{\mathrm{x}}$ concentrations in the west. Based on measurements from three intensive field campaigns at two European coastal sites (Mace Head, Ireland and Weybourne, UK) it was shown that the calculated ozone production efficiency in clean oceanic air masses was approximately 65 , which was in contrast to values between 4 and 6 for more polluted air masses from the U.K. and continental Europe (Rickard et al., 2002).

It was pointed out in Sect. 2.2 that the $\mathrm{NO}_{\mathrm{y}} / \mathrm{CO}$ ratio could be used as an alternative suitable method to distinguish between disturbed FT conditions (air masses influenced by recent emissions) and undisturbed FT conditions (aged air masses) at the JFJ. The experimentally derived daily $E_{N}$ values versus the respective daily values of the ratio $\mathrm{NO}_{\mathrm{y}} / \mathrm{CO}$ show a general decreasing exponential trend in $E_{N}$ with increasing $\mathrm{NO}_{\mathrm{y}} / \mathrm{CO}$ (Fig. 5) which is in agreement with previous studies which have shown the exponential decrease of $E_{N}$ as $\mathrm{NO}_{\mathrm{x}}$ levels increase (e.g. Liu et al., 1987; Carpenter et al., 2000; Rickard et al., 2002). Caution must be exer- cised in the implication of photochemistry in such correlations, because a relationship would also be expected if $\mathrm{O}_{3}$ and $\mathrm{NO}_{\mathrm{z}}$ were exported from a common source and consequently diluted. However, if this were the case, the $\mathrm{O}_{3} / \mathrm{NO}_{\mathrm{z}}$ ratio would not be expected to change, whereas Fig. 5 reveals the expected decrease of $E_{N}$ with concentration of oxidized nitrogen. It should also be noted that for the vast majority of the daily values the $\mathrm{NO}_{\mathrm{y}} / \mathrm{CO}$ ratio is lower than 0.01 . Stohl et al. (2002) reported that the $\mathrm{NO}_{\mathrm{y}} / \mathrm{CO}$ ratio dropped to values below 0.01 for air masses older than four days in the continental outflow region of North America, where warm conveyer belts are responsible for the vertical lifting of pollutants.

Theoretical values of $E_{N}$ were calculated by the steady state Eq. (2) for varying $\mathrm{NO}_{\mathrm{y}} / \mathrm{CO}$ by setting the levels of $\mathrm{O}_{3}$, $\mathrm{CO}, \mathrm{H}_{2} \mathrm{O}$, temperature, pressure, $\mathrm{NO} / \mathrm{NO}_{\mathrm{x}}$ and $\mathrm{NO}_{\mathrm{x}} / \mathrm{NO}_{\mathrm{y}}$ to their median values from the measurements carried out at JFJ from 1998 to 2004 . These theoretically derived $E_{N}$ values for varying $\mathrm{NO}_{\mathrm{y}} / \mathrm{CO}$ levels are shown with a black solid line in Fig. 5, which compares rather well with the general decreasing exponential trend from the experimentally derived $E_{N}$ values. Nevertheless, the experimentally derived $E_{N}$ values show a scatter around the theoretical curve. Since $E_{N}$ is mainly sensitive to $\mathrm{NO}$ and $\mathrm{NO}_{2}$ as pointed in Sect. 2.3, in order to illustrate uncertainty of the theoretically derived $E_{N}$ curve, we calculated $E_{N}$ values from the steady state Eq. (2) for varying $\mathrm{NO}_{\mathrm{y}} / \mathrm{CO}$ by setting the ratios $\mathrm{NO} / \mathrm{NO}_{\mathrm{x}}$ and $\mathrm{NO}_{\mathrm{x}} / \mathrm{NO}_{\mathrm{y}}$ to their 1 st and 3rd quartile values of the 1998-2004 record (instead of their median values) while keeping all the other variables $\left(\mathrm{O}_{3}, \mathrm{CO}, \mathrm{H}_{2} \mathrm{O}\right.$, temperature, pressure) constant at their median values. The $\mathrm{E}_{N}$ values for 1st and 3rd quartiles are displayed as dashed lines in Fig. 5. While the theoretical values cover most of the higher $E_{N}$ values, most of the lower $E_{N}$ cases are not covered by the theoretical estimation which might be attributed to the fact that PAN and PNA formation can lower the $E_{N}$ values but their influence is not included in Eq. (2).

\subsection{Seasonality of $E_{N}$ with respect to undisturbed and dis-} turbed FT conditions

The experimentally derived daily $E_{N}$ values of Fig. 5 and the daily intercept values have been used to calculate the monthly mean values. These monthly means of experimentally derived $E_{N}$ and intercept values are illustrated in Fig. 6 along with the monthly means of the respective $\mathrm{NO}_{\mathrm{y}} / \mathrm{CO}$ values and the frequency of the selected days per month from which the monthly means were calculated.

Note from Fig. 6 that the highest frequencies of the selected days per month, for which daily values of $E_{N}$ were experimentally derived, are observed during March, April and May. The monthly means of experimentally derived daily $E_{N}$ values show a seasonal variation with lower values during the warm period from May to August, which is accompanied by higher values of the $\mathrm{NO}_{\mathrm{y}} / \mathrm{CO}$ ratio. The seasonal 
variation in the $\mathrm{NO}_{\mathrm{y}} / \mathrm{CO}$ ratio can be attributed on the one hand to a longer lifetime of $\mathrm{CO}$ during the cold season and on the other hand to enhanced vertical transport during the warm season. However, the fact that the $\mathrm{NO}_{\mathrm{y}} / \mathrm{CO}$ level in April is comparable with the $\mathrm{NO}_{\mathrm{y}} / \mathrm{CO}$ levels from May to September is primarily due to the peak $\mathrm{NO}_{\mathrm{y}}$ concentration in April (see Fig. 2 and Fig. 3). This cannot be attributed to thermal vertical mixing but rather to other transport processes of polluted air masses from regional to hemispheric scale. It can be inferred from Fig. 6 that the seasonal variation of $E_{N}$ values with lower values from May to August can be partially attributed to more efficient vertical transport of polluted air masses from the atmospheric boundary layer up to JFJ during the warm period.

The monthly means of the intercept, which reflects the background ozone, were calculated from the daily intercept values and demonstrate a seasonal cycle oscillating around a mean level of $43 \pm 3$ ppbv (the error bar denotes the $95 \%$ confidence interval of the mean) with amplitude ranging from about $35 \mathrm{ppbv}$ in winter months to about $50 \mathrm{ppbv}$ within the period between April and August.

Figure 6 also shows that the monthly means of experimentally derived $E_{N}$ values compare rather well with theoretically derived $E_{N}$ values. Both experimentally and theoretically derived $E_{N}$ values demonstrate similar seasonal variation. The theoretical monthly $E_{N}$ values were calculated from the steady state Eq. (2) by setting the levels of $\mathrm{NO}, \mathrm{NO}_{2}, \mathrm{O}_{3}, \mathrm{CO}, \mathrm{H}_{2} \mathrm{O}$, temperature and pressure to their median monthly values from the daily mean values of the 571 selected days. In order to get a range for the theoretical monthly $E_{N}$ values, we calculated $E_{N}$ values from the steady state Eq. (2) by varying the respective monthly median values of $\mathrm{NO}, \mathrm{NO}_{2}, \mathrm{O}_{3}, \mathrm{CO}, \mathrm{H}_{2} \mathrm{O}$, temperature and pressure by $10 \%$.

Taking into account the results by Zellweger et al. (2003), who showed from measurements of $\mathrm{NO}_{\mathrm{y}}$ and $\mathrm{CO}$ at JFJ that undisturbed FT conditions are always accompanied by the lowest $\mathrm{NO}_{\mathrm{y}} / \mathrm{CO}$ ratios, we used this ratio to distinguish between disturbed and undisturbed FT conditions at the JFJ. Initially, the experimentally derived $E_{N}$ values were disaggregated in two large classes in order to use all the available data for the calculations, one class including days when the respective daily $\mathrm{NO}_{\mathrm{y}} / \mathrm{CO}$ value was lower than the median monthly value of the ratio $\mathrm{NO}_{\mathrm{y}} / \mathrm{CO}$ (less disturbed FT conditions) and one class including days when the respective daily $\mathrm{NO}_{\mathrm{y}} / \mathrm{CO}$ value was higher than the median monthly value of the ratio $\mathrm{NO}_{\mathrm{y}} / \mathrm{CO}$ (more disturbed FT conditions). The monthly means of $E_{N}$ values, which were calculated for these two individual classes $\left(\mathrm{NO}_{\mathrm{y}} / \mathrm{CO}<\right.$ median and $\mathrm{NO}_{\mathrm{y}} / \mathrm{CO}>$ median) at $\mathrm{JFJ}$, are illustrated in Fig. 7a indicating that the monthly means of experimentally derived $E_{N}$ values for the less disturbed FT conditions $\left(\mathrm{NO}_{\mathrm{y}} / \mathrm{CO}<\right.$ median) are generally higher than the respective monthly $E_{N}$ values for the more disturbed FT conditions $\left(\mathrm{NO}_{\mathrm{y}} / \mathrm{CO}>\right.$ median) except in November and January.
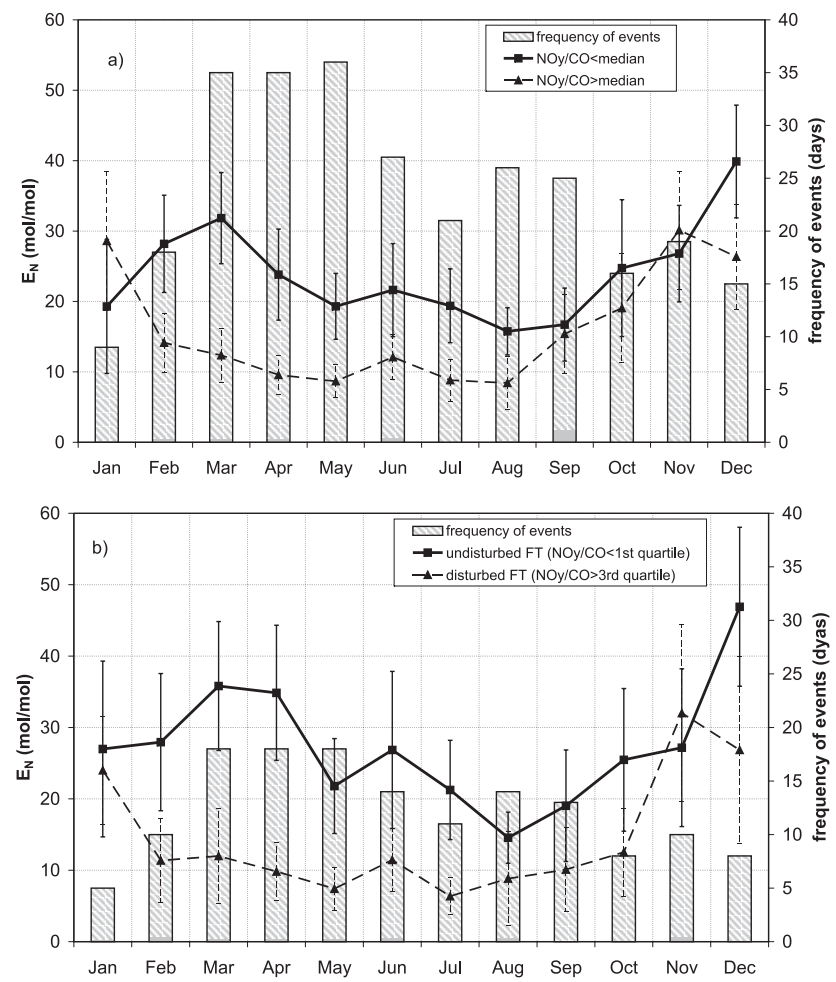

Fig. 7. (a) Seasonal variation of monthly means of experimentally derived $E_{N}\left(\Delta \mathrm{O}_{3} / \Delta \mathrm{NO}_{z}\right)$ values (a) for days that the respective daily $\mathrm{NO}_{\mathrm{y}} / \mathrm{CO}$ value was lower (or higher) than the median monthly value of the ratio $\mathrm{NO}_{\mathrm{y}} / \mathrm{CO}$ and (b) for days that the respective daily $\mathrm{NO}_{\mathrm{y}} / \mathrm{CO}$ value was lower than the monthly $1^{\text {st }}$ quartile value of the ratio $\mathrm{NO}_{\mathrm{y}} / \mathrm{CO}$ (characterised as undisturbed FT conditions) or higher than the monthly 3rd quartile value of the ratio $\mathrm{NO}_{\mathrm{y}} / \mathrm{CO}$ (characterised as disturbed FT conditions). The frequency of the days per month from which the respective monthly $E_{N}$ values were calculated is superimposed with grey column bars. Error bars denote $95 \%$ confidence interval of the monthly mean values of $E_{N}$.

However, this separation method in two classes based on the median value of $\mathrm{NO}_{\mathrm{y}} / \mathrm{CO}$ is rather crude and hence a stricter criterion was applied to disaggregate the daily $E_{N}$ values using the 1 st and 3rd quartile monthly values of the $\mathrm{NO}_{\mathrm{y}} / \mathrm{CO}$ ratio (see Table 1). A day was characterised as undisturbed FT if the respective daily $\mathrm{NO}_{\mathrm{y}} / \mathrm{CO}$ value was lower than the monthly 1 st quartile value of the $\mathrm{NO}_{\mathrm{y}} / \mathrm{CO}$ ratio while a day was characterised as disturbed FT if the respective daily $\mathrm{NO}_{\mathrm{y}} / \mathrm{CO}$ value was higher than the monthly 3rd quartile value of the $\mathrm{NO}_{\mathrm{y}} / \mathrm{CO}$ ratio. Indicatively, the $1^{s t}$ quartile value of the $\mathrm{NO}_{\mathrm{y}} / \mathrm{CO}$ ratio ranges from 0.0020 in February to 0.0075 in July, while the 3rd quartile value of the $\mathrm{NO}_{\mathrm{y}} / \mathrm{CO}$ ratio ranges from 0.0054 in December to 0.0128 in July (see Table 1). Table 1 also shows that the respective seasonal 1st quartile values of the $\mathrm{NO}_{\mathrm{y}} / \mathrm{CO}$ ratio range from 0.0022 in winter (DJF) to 0.0063 in summer (JJA) with spring (MAM) and autumn (SON) values being around 0.004 . These 1 st quartile $\mathrm{NO}_{\mathrm{y}} / \mathrm{CO}$ ratio values in winter, 
Table 1. Monthly, seasonal and annual statistics of the $\mathrm{NO}_{\mathrm{y}} / \mathrm{CO}$ values for the 571 selected days between 1998 and 2004 .

\begin{tabular}{lcccccc}
\hline & Min & 1 stQu & Median & Mean & 3rdQu & Max \\
\hline January & 0.0007 & 0.0025 & 0.0041 & 0.0046 & 0.0069 & 0.0087 \\
February & 0.0015 & 0.0020 & 0.0035 & 0.0046 & 0.0069 & 0.0130 \\
March & 0.0015 & 0.0024 & 0.0041 & 0.0054 & 0.0070 & 0.0197 \\
April & 0.0026 & 0.0052 & 0.0075 & 0.0080 & 0.0107 & 0.0163 \\
May & 0.0032 & 0.0053 & 0.0070 & 0.0079 & 0.0093 & 0.0163 \\
June & 0.0028 & 0.0054 & 0.0081 & 0.0083 & 0.0112 & 0.0160 \\
July & 0.0027 & 0.0075 & 0.0093 & 0.0102 & 0.0128 & 0.0219 \\
August & 0.0028 & 0.0062 & 0.0076 & 0.0082 & 0.0094 & 0.0163 \\
September & 0.0025 & 0.0060 & 0.0075 & 0.0083 & 0.0096 & 0.0204 \\
October & 0.0014 & 0.0034 & 0.0045 & 0.0058 & 0.0066 & 0.0150 \\
November & 0.0015 & 0.0033 & 0.0055 & 0.0055 & 0.0067 & 0.0164 \\
December & 0.0013 & 0.0021 & 0.0037 & 0.0042 & 0.0054 & 0.0132 \\
\hline Winter & 0.0007 & 0.0022 & 0.0037 & 0.0045 & 0.0064 & 0.0132 \\
Spring & 0.0015 & 0.0041 & 0.0062 & 0.0071 & 0.0092 & 0.0197 \\
Summer & 0.0027 & 0.0063 & 0.0081 & 0.0088 & 0.0113 & 0.0219 \\
Autumn & 0.0014 & 0.0042 & 0.0059 & 0.0067 & 0.0084 & 0.0204 \\
\hline Annual & 0.0007 & 0.0041 & 0.0066 & 0.0071 & 0.0092 & 0.0219 \\
\hline
\end{tabular}

spring and autumn are in agreement with the respective seasonal values indicated from meteorological analysis by Zellweger et al. (2003) for undisturbed FT conditions. Only the 1st quartile $\mathrm{NO}_{\mathrm{y}} / \mathrm{CO}$ ratio value in summer is slightly higher than the respective summer value indicated in the study of Zellweger et al. (2003) for undisturbed FT conditions but within the standard error. It should always be kept in mind that this selection criterion, to use the 1st and 3rd quartile monthly value of the $\mathrm{NO}_{\mathrm{y}} / \mathrm{CO}$ ratio, is not an absolute way to distinguish between disturbed and undisturbed FT conditions but only a relative way to sample air masses with different characteristics. Hence, the relative selection criterion with upper and lower quartiles is a compromise in order to have an adequate number of days per month for the calculation of monthly $E_{N}$ values. For example when using an absolute criterion for the $\mathrm{NO}_{\mathrm{y}} / \mathrm{CO}$ ratio being lower than a value of around 0.004 , only a few days were selected from May to September.

Following this methodology with the 1st and 3rd quartile monthly values of the $\mathrm{NO}_{\mathrm{y}} / \mathrm{CO}$ ratio as cut-off values, the experimentally derived daily $E_{N}$ values were disaggregated into two classes for disturbed and undisturbed FT conditions at JFJ. The monthly means of $E_{N}$ values, which were calculated for these two individual classes (disturbed and undisturbed FT conditions) at JFJ, are illustrated in Fig. 7b along with the frequency of the undisturbed FT (or disturbed FT) days per month used for the calculation of the monthly $E_{N}$ value. As it can be inferred from Fig. 7a and b the use of a more strict criterion with the 1st and 3rd quartile monthly values of the $\mathrm{NO}_{\mathrm{y}} / \mathrm{CO}$ ratio as cut-off values results into a clearer distinction between the monthly means of $E_{N}$ val- ues of the selected classes, indicating the consistency of the filtering methodology. The annual mean $E_{N}$ value for undisturbed FT conditions ( $<1$ st quartile) is $27.4 \pm 4.9$ molecules of $\mathrm{O}_{3}$ produced per molecule of $\mathrm{NO}_{\mathrm{x}}$ oxidized, while for disturbed FT conditions ( $>3$ rd quartile) it is $14.4 \pm 4.7$ (the error bars denotes the $95 \%$ confidence interval of the mean). The monthly means of experimentally derived $E_{N}$ values for the undisturbed FT conditions are generally higher than the respective monthly $E_{N}$ values for the disturbed FT conditions except in November. This reflects the expected decrease of $E_{N}$ with increasing concentration of oxidized nitrogen. The monthly mean $E_{N}$ values for the disturbed FT conditions are around 10 for all months from February to October with no distinct seasonal pattern while the monthly $E_{N}$ values for the undisturbed FT conditions show a distinct seasonal cycle with higher values in the cold season from November to April.

If we disregard the peak monthly $E_{N}$ value of December $\left(E_{N}=46.9\right)$ for undisturbed FT conditions, which was calculated from only 8 days, the monthly $E_{N}$ values of March $\left(E_{N}=35.8\right)$ and April $\left(E_{N}=34.9\right)$ are the highest values throughout the year for undisturbed FT conditions at JFJ. In addition these high $E_{N}$ values of March and April result from the highest frequencies of selected days per month with undisturbed FT conditions (18 days for both months) (see Fig. 7b). It should be noted that the monthly $E_{N}$ values for the disturbed FT conditions from November to January are higher than 24 and almost comparable with the monthly $E_{N}$ values for the undisturbed FT conditions (except in December), which implies that the criterion used to disaggregate disturbed and undisturbed FT conditions for these months is 
not a distinct selection rule. The difference of $E_{N}$ values between undisturbed FT and disturbed FT conditions during the warm period of the year from May to September can be partially attributed to more frequent and apparent episodes with thermally induced vertical transport of polluted air masses from the atmospheric boundary layer up to JFJ. However, the difference of $E_{N}$ values between undisturbed FT and disturbed FT in February, March and April cannot be associated to more efficient thermal vertical mixing but rather to other transport processes of polluted air masses from regional to hemispheric scale.

Preliminary analysis of the back trajectories for the disturbed and undisturbed FT days in April using the British Atmospheric Data Centre (BADC) trajectory tool (http://badc. nerc.ac.uk) which derived the parcel paths from the ECMWF analysed winds with $2.5^{\circ} \times 2.5^{\circ}$ resolution points to transport processes from regional scale (such as dynamical uplifting within synoptic frontal systems) to hemispheric scale (intercontinental transport) as a source of pollutants (and hence of precursors for ozone production) at the lower FT during early spring. However, taking into account the trajectory uncertainties associated with the low resolution of the wind fields and the complexity of the alpine topography there is an effort in progress to investigate in detail the origin of the air masses for undisturbed and disturbed FT conditions during spring with more elaborate trajectory tools and meteorological analysis.

The monthly $E_{N}$ values for the undisturbed FT conditions (shown in Fig. 7b) can be multiplied with the respective observed monthly $\mathrm{NO}_{z}$ values (shown in Fig. 8), to obtain the monthly quantity $\Delta \mathrm{O}_{3}$. Taking into account the respective monthly ozone production efficiency, the quantity $\Delta \mathrm{O}_{3}$ reflects how much ozone would be produced on the way to JFJ if all the observed monthly $\mathrm{NO}_{z}$ concentration at JFJ were obtained from the oxidation of $\mathrm{NO}_{\mathrm{x}}$ following the way to JFJ. As can be noted from Fig. 8 the monthly mean values of the quantity $\Delta \mathrm{O}_{3}$ show a rather similar seasonal variation with the respective observed monthly $\mathrm{O}_{3}$ values (as calculated from the days with undisturbed FT conditions at JFJ) with a peak in April. The $\Delta \mathrm{O}_{3}$ builds up on the monthly ozone background as reflected from the respective monthly intercept value of the regression. Hence calculated monthly ozone values were derived from the addition of the monthly $\Delta \mathrm{O}_{3}$ values and the respective monthly intercept values for undisturbed FT conditions. Figure 8 indicates that these calculated monthly ozone values show good agreement with the observed monthly ozone values for undisturbed FT conditions. It is apparent that the seasonal cycle in calculated monthly ozone values results from both the seasonal dependence of $E_{N}$ and the seasonal dependence of $\mathrm{NO}_{\mathrm{z}}$.

The evidences from Fig. $7 \mathrm{~b}$ and Fig. 8 highlight the great potential and importance of photochemical ozone production in the FT during the spring season, thus indicating a key and possibly dominant role for photochemistry in the observed build-up of tropospheric ozone in the winter-spring transi-

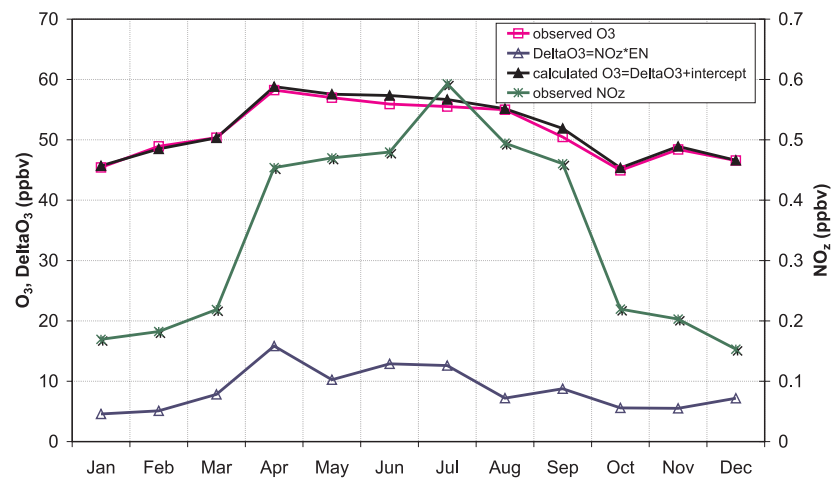

Fig. 8. Seasonal variation of monthly means of observed $\mathrm{O}_{3}$ (pink open squares) and $\mathrm{NO}_{\mathrm{Z}}$ (green asterisks) concentrations calculated from the days with undisturbed FT conditions at JFJ from 1998 to 2004. With blue open triangles are illustrated monthly $\Delta \mathrm{O}_{3}$ values derived from the multiplication of the monthly experimentally derived $E_{N}$ values for undisturbed FT conditions with the respective monthly observed $\mathrm{NO}_{\mathrm{Z}}$ values. With solid black triangles are illustrated calculated ozone values derived from the addition of the monthly $\Delta \mathrm{O}_{3}$ values and the respective monthly intercept values for undisturbed FT conditions.

tion period. This is in line with the findings of FREETEX campaigns between 1996 and 2001 (Zanis et al., 2003).

\section{Summary and conclusions}

In this study we investigate the seasonal variability of ozone productions efficiencies $\left(E_{N}\right)$ at the high-alpine research station Jungfraujoch (JFJ) based on continuous measurements of nitrogen oxide (NO), nitrogen dioxide $\left(\mathrm{NO}_{2}\right)$, total reactive nitrogen $\left(\mathrm{NO}_{\mathrm{y}}\right)$ and ozone $\left(\mathrm{O}_{3}\right)$ carried out regularly for a seven-year period (1998-2004). This dataset is a unique long-term data series of nitrogen levels in the FT over Central Europe and hence it provides an excellent opportunity to perform such an analysis.

A striking feature is the monthly peak values of $\mathrm{NO}_{\mathrm{y}}, \mathrm{NO}_{\mathrm{z}}$, and $\mathrm{NO}_{\mathrm{x}}$ in April, which is a consistent feature for most of the individual years between 1998 and 2004 in accordance with the $\mathrm{CO}$ observations. This feature cannot be associated to thermally induced vertical transport from the boundary layer but rather to larger scale transport processes of polluted air masses from regional to hemispheric scale.

Experimentally derived daily $E_{N}$ values have been selected for 571 days out of the 2557 days from 1998 to 2004 , from which an average ozone production efficiency of $18.8 \pm 1.3$ molecules of $\mathrm{O}_{3}$ produced per molecule of $\mathrm{NO}_{\mathrm{x}}$ oxidized was calculated. This $E_{N}$ value, which is comparable with the $E_{N}$ value of $21.5 \pm 1.9$ derived from the monthly means of $\mathrm{O}_{3}$ and $\mathrm{NO}_{\mathrm{z}}$ at JFJ from 1998 to 2004, indicates the great potential and importance of photochemical ozone production in the FT. In agreement with theoretical steadystate calculations, these experimentally derived daily $E_{N}$ val- 
ues exhibited a general decreasing exponential trend with increasing $\mathrm{NO}_{\mathrm{y}} / \mathrm{CO}$ ratio, a parameter to assess the aging process that has occurred in an air parcel.

The monthly means of experimentally derived daily $E_{N}$ values showed a seasonal variation with lower values from May to August, which can be partially attributed to more efficient vertical transport of polluted air masses from the atmospheric boundary layer up to JFJ during the warm period. Both experimentally and theoretically derived $E_{N}$ values demonstrate a similar seasonal variation.

Taking into account that undisturbed FT conditions are always accompanied by the lowest $\mathrm{NO}_{\mathrm{y}} / \mathrm{CO}$ ratios, we used the 1 st and 3rd quartile values of this ratio to disaggregate the experimentally derived daily $E_{N}$ values into two classes for disturbed and undisturbed FT conditions at JFJ. The monthly means of experimentally derived $E_{N}$ values for the undisturbed FT conditions are generally higher than the respective monthly $E_{N}$ values for the disturbed FT conditions except in November, which reflects the expected decrease of $E_{N}$ with increasing concentration of oxidized nitrogen and pollution levels in the disturbed FT conditions. The monthly mean $E_{N}$ values for the disturbed FT conditions are relatively constant and remain around 10 for all months from February to October while the monthly $E_{N}$ values for the undisturbed FT conditions show a distinct seasonal cycle with higher values in the cold season from November to April.

The monthly $E_{N}$ values of March $\left(E_{N}=35.8\right)$ and April $\left(E_{N}=34.9\right)$ are among the highest values throughout the year for undisturbed FT conditions at JFJ. Furthermore, the monthly mean values of the quantity $\Delta \mathrm{O}_{3}$, which reflects how much ozone would be produced in a month from the oxidation of $\mathrm{NO}_{\mathrm{x}}$ to the observed monthly $\mathrm{NO}_{\mathrm{z}}$ concentration taking into account the respective monthly ozone production efficiency, show a rather similar seasonal variation with the respective monthly $\mathrm{O}_{3}$ values with a peak in April. These results highlight the key and possibly the dominant role for photochemistry in the observed build-up of tropospheric ozone in the winter-spring transition period.

Acknowledgements. We acknowledge that the International Foundation High Altitude Research Stations Jungfraujoch and Gornergrat (HFSJG), made it possible to carry out our measurements. Measurements were made by the Swiss National Air Pollution Monitoring Network (NABEL) on behalf of the Swiss Federal Office for the Environment (FOEN). The financial support of the NABEL network by FOEN is highly acknowledged.

Edited by: N. Mihalopoulos

\section{References}

Baltensperger, U., Gäggeler, H. W., Jost, D. T., Lugauer, M., Schwikowski, M., and Seibert, P.: Aerosol climatology at a high Alpine site Jungfraujoch, Switzerland, J. Geophys. Res., 102(D16), 19707-19715, 1997.
Brönnimann, S.: Early Spring Ozone Episodes: Occurrence and Case Study, Phys. Chem. Earth, Part C, 24(5), 531-536, 1999.

Campana, M., Li, Y., Staehelin, J., Prévôt, A. S. H., Bonasoni, P., Loetscher, H., and Peter, T.: The in?uence of south foehn on the ozone mixing ratios at the high alpine site Arosa, Atmos. Environ., 39, 2945-2955, 2005.

Carpenter, L. J., Green, T. J., Mills, G. P., Bauguitte, S., Penkett, S. A., Zanis, P., Schuepbach, E., Schmidbauer, N., Monks, P. S., and Zellweger, C.: Oxidised nitrogen and ozone production efficiencies in the springtime free troposphere over the Alps, J. Geophys. Res., 105, 14 547-14 559, 2000.

Chin, M., Jacob, D. J., Munger, J. W., Parrish, D. D., and Doddridge, B. G.: Relationship of ozone and carbon monoxide over North America, J. Geophys. Res., 99, 14 565-14 573, 1994.

Crutzen, P. J.: Tropospheric ozone: An overview, in: Tropospheric Ozone, edited by: I.S.A. Isaksen, D. Reidel Publ. Co., 3-32, 1988.

Crutzen, P. J., Lawrence, M. G., and Poeschl, U.: On the background photochemistry of tropospheric ozone, Tellus, 51A-B 123-146, 1999.

Davies, T. D. and Schuepbach, E.: Episodes of high ozone concentrations at the earth's surface resulting from transport down from the upper troposphere/lower stratosphere: A review and case studies, Atmos. Environ., 28(1), 53-68, 1994.

DeWekker, S. F. J., Steyn, D. G. and Nyeki, S.: A Comparison of Aerosol-layer and Convective Boundary Layer Structure Over a Mountain Range During STAAARTE '97, Bound. Lay. Met., 113, 249-271, 2004.

Emmons, L. K., Carroll, M. A., Hauglustaine, D. A., Brasseur, G. P., et al.: Climatologies of $\mathrm{NO}_{\mathrm{x}}$ and $\mathrm{NO}_{\mathrm{y}}$ : A comparison of data and models, Atmos. Environ., 31(12), 1851-1904, 1997.

Forrer, J., Rüttimann, R., Schneiter, D., Fischer, A., Buchmann, B., and Hofer, P.: Variability of trace gases at the high Alpine site Jungfraujoch caused by meteorological transport processes, J. Geophys. Res., 105, 12 241-12 251, 2000.

Jaeglé, L., Jacob, D. J., Wang, Y., Weinheimer, A. J., Ridley, B. A., Campos, T. L., Sachse, G. W., and Hagen, D. E.: Sources and chemistry of $\mathrm{NO}_{\mathrm{x}}$ in the upper troposphere over the United States, Geophys. Res. Lett., 25, 1705-1708, 1998.

Henne, S., Furger, M., Nyeki, S., Steinbacher, M., Neininger, B., De Wekker, S. F. J., Dommen, J., Spichtinger, N., Stohl, A., and Prévôt, A. S. H.: Quantification of Topographic Venting of Boundary Layer Air to the Free Troposphere, Atmos. Chem. Phys., 4, 497-509, 2004, http://www.atmos-chem-phys.net/4/497/2004/.

Henne, S., Furger, M., and Prévôt, A. S. H.: Climatology of Mountain Venting - Induced Elevated Moisture Layers in the Lee of the Alps, J. Appl. Meteo., 44(5), 620-633, 2005a.

Henne, S., Dommen, J., Neininger, B., Reimann, S., Staehelin, J., and Prévôt, A. S. H.: Influence of Mountain Venting in the Alps on the Ozone Chemistry of the Lower Free Troposphere and the European Pollution Export, J. Geophys. Res., 110(D22), D22307, doi:10.1029/2005JD005936, 2005b.

Hirsch, A. I., Munger, J. W., Jacob, D. J., Horowitz, L. W., and Goldstein, A. H.: Seasonal variation of ozone production efficiency per unit $\mathrm{NO}_{\mathrm{x}}$ at Harvard National Forest, Massachusetts, J. Geophys. Res., 101, 12 659-12 666, 1996.

Hough, A. M.: The calculation of photolysis rates for use in global tropospheric modelling studies, AERE Rep. R-13259, pp. 53 
Her Majesty's Stn. Off., Norwich, England, 1988.

Lacis, A. A., Wuebbles, D. J., and Logan, J. A.: Radiative forcing of climate by changes in the vertical distribution of ozone, $\mathrm{J}$. Geophys. Res., 95, 9971-9981, 1990.

Lelieveld, J. and Dentener, F.: What controls tropospheric ozone, J. Geophys. Res., 105(3), 3543-3563, 2000.

Li, Y., Campana, M., Reimann, S., Schaub, D., Stemmler, K., Staehelin, J., and Peter, T.: Hydrocarbon concentrations at the Alpine mountain sites Jungfraujoch and Arosa, Atmos. Environ., 39, 1113-1127, 2005.

Liu, S. C., Trainer, M., Fehsenfeld, F. C., Parrish, D. D., Williams, E. J., Fahey, D. W., Hübler, G., and Murphy, P. C.: Ozone Production in the Rural Troposphere and the Implications for Regional and Global Ozone Distributions, J. Geophys. Res., 92(D4), 4191-4207, 1987.

Logan, J. A.: Nitrogen oxides in the troposphere: Global and regional budgets, J. Geophys. Res., 88, 10 785-10 807, 1983.

Lugauer M., Baltensperger, U., Furger, M., Gäggeler, H. W., Jost, D. T., Schwikowski, M., and Wanner, H.: Aerosol transport to the high Alpine sites Jungfraujoch (3454 m asl) and Colle Gnifetti (4452 $\mathrm{m}$ asl). Tellus, 50B, 76-92, 1998.

Lugauer, M., Baltensperger, U., Furger, M., Gäggeler, H. W., Jost, D. T., Nyeki, S., and Schwikowski, M.: Influences of vertical transport and scavenging on aerosol particle surface area and radon decay product concentrations at the Jungfraujoch $(3454 \mathrm{~m}$ above sea level), J. Geophys. Res., 105, 19 869-19 879, 2000.

Monks, P. S.: A review of observations and origins of the spring ozone maximum, Atmos. Environ., 34, 3545-3561, 2000.

Nyeki, S., Kalberer, M., Colbeck, I., De Wekker, S., Furger, M., Gäggeler, H. W., Kossmann, M., Lugauer, M., Steyn, D., Weingartner, E., Wirth, M., and Baltensperger, U.: Convective boundary layer evolution to $4 \mathrm{~km}$ asl over high-alpine terrain: Airborne lidar observations in the Alps, Geophys. Res. Lett., 27, 689-692, 2000.

Nunnermacker, L. J., Imre, D., Daum, P. H., Kleinman, L., Lee, Y. N., Lee, J. H., Springston, S. R., Newman, L., Weinstein-Lloyd, J., Luke, W. T., Banta, R., Alvarez, R., Senff, C., Sillman, S., Holdren, M., Keigley, G. W., and Zhou, X.: Charaterization of the Nashville urban plume on July 3 and July 18, 1995, J. Geophys. Res., 103(D21), 28 129-28 148, 1998.

Olszyna, K. J., Bailey, E. M., Simonaitis, R., and Meagher, J. F.: $\mathrm{O}_{3}$ and $\mathrm{NO}_{\mathrm{y}}$ relationships at a rural site, J. Geophys. Res., 99, 14 557-14 563, 1994.

Ordonez C., Mathis U., Furger M., Henne S., Hüglin C., Staehelin J., and Prévôt, A. S. H.: Changes of daily surface ozone maxima in Switzerland in all seasons from 1992 to 2002 and discussion of summer 2003, Atmos. Chem. Phys., 5 1187-1203, 2005.

Parrish, D. D., Trainer, M., Buhr, M. P.,Watkins, B. A., and Fehsenfeld, F. C.: Carbon monoxide concentrations and their relation to concentrations of total reactive oxidized nitrogen at two rural U.S. sites, J. Geophys. Res., 96, 9309-9320, 1991.

Penkett, S. A. and Brice, K. A.: The spring maximum in photooxidant in the Northern hemisphere troposphere, Nature, 319, 655-657, 1986.

Penkett, S. A.: Indications and causes of ozone increase in the troposphere, in: The changing atmosphere, edited by: Rowland, F. S. and Isaksen, I. S. A., J. Wiley \& Sons, 91, 1988.

Prévôt, A. S. H., Staehelin, J., Kok, G. L., Schillawski, R. D., Neininger, B., Staffelbach, T., Neftel, A., Wernli, H., and Dom- men, J.: The Milan photooxidant plume, J. Geophys. Res., 102, 23 375-23 388, 1997.

Rickard, A. R., Salisbury, G., Monks, P. S., Lewis, A. C., Baugitte, S., Bandy, B. J., Clemitshaw, K. C., and Penkett, S. A.: Comparison of measured ozone production efficiencies in the marine boundary layer at two European coastal sites under different pollution regimes, J. Atmos. Chem., 43, 107-134, 2002.

Sander, S. P., De More, W. B., Howard, C. J., Ravishankara, A. R., Golden, D. M., Kolb, C. E., Hampson, R. F., Kurylo, M. J., and Molina, M. J.: Chemical kinetics and photochemical data for use in stratospheric modeling, evaluation number 12, National Aeronautics and Space Administration, Jet Propulsion Laboratory, JPL Publication 97-4, 2003.

Schär, C., Vidale, P. L., Lüthi, D., Frei, C., Häberli, C., Liniger, M. A., and Appenzeller, C.: The role of increasing temperature variability in European summer heatwaves, Nature, 427, 332 336, doi:10.1038/nature02300, 2004.

Schuepbach, E., Friedli, T. K., Zanis, P., Monks, P. S., and Penkett, S. A.: State space analysis of trends and seasonalities of lower free tropospheric ozone (1988-1997) at the high elevation site at Jungfraujoch, J. Geophys. Res., 106(D17), 20 413-20 427, 2001.

Schüepp, M.: Witterungsklimatologie, Beiheft zu den Annalen der Sz. Meterol. Anstalt 20, 93 pp, 1979.

Sillman, S., Logan, J. A., and Wofsy, S .C.: The sensitivity of ozone to nitrogen oxides and hydrocarbons in regional ozone episodes, J. Geophys. Res., 95(D2), 1837-1851, 1990.

Staehelin, J. and Schmid, W.: Trend analysis of tropospheric ozone concentrations utilizing the 20-year data set of ozone balloon soundings over Payerne (Switzerland), Atmos. Environ., 25A(9), 1739-1749, 1991.

Staehelin, J., Thudium, J., Buehler, R., Volz-Thomas, A., and Graber, W.: Trends in surface ozone concentrations at Arosa (Switzerland), Atmos. Environ., 28(1), 75-87, 1994.

Stohl, A., Trainer, M., Ryerson, T. B., Holloway, J. S., and Parrish, D. D.: Export of $\mathrm{NO}_{\mathrm{y}}$ from the North American boundary layer during NARE 96 and NARE 97, J. Geophys. Res., 107(D11), 4131, doi:10.1029/2001JD000519, 2002.

Stohl, A., Bonasoni, P., Cristofanelli, P., Collins, W., Feichter, J., Frank, A., Forster, C., Gerasopoulos, E., Gäggeler, H., James, P., Kentarchos, T., Kreipl, S., Kromp-Kolb, H., Krüger, B., Land, C., Meloen, J., Papayannis, A., Priller, A., Seibert, P., Sprenger, M., Roelofs, G. J., Scheel, E., Schnabel, C., Siegmund, P., Tobler, L., Trickl, T., Wernli, H., Wirth, V., Zanis, P., and Zerefos, C.: Stratosphere-troposphere exchange - a review, and what we have learned from STACCATO, J. Geophys. Res., 108(D12), doi:10.1029/2002JD002490, 2003.

Thielmann, A., Prévôt, A.S.H., and Staehelin, J.: Sensitivity of ozone production derived from field measurements in the Italian Po basin, J. Geophys. Res., 107(D22), 8194, doi:10.1029/2000JD000119, 2002.

Trainer, M., Parrish, D. D., Buhr, M. P., Norton, R. B., Feshenfeld, F. C., Anlauf, K. G., Bottenheim, J. W., Tang, Y. Z., Wiebe, H. A., Roberts, J. M., Tanner, R. L., Newman, L., Bowersox, V. C., Meagher, J. F., Olszyna, K. J., Rodgers, M. O., Wang, T., Berresheim, H., Demerjian, K. L., and Roychowdhury, U. K.: Correlation of ozone with $\mathrm{NO}_{\mathrm{y}}$ in photochemically aged air, J. Geophys. Res., 98, 2917-2985, 1993.

Volz-Thomas, A. and Kley, D.: Evaluation of the Montsouris series of ozone measurements made in the nineteenth century, Nature, 
332, 240-242, 1988.

Wanner, H., Salvisberg, E., Rickli, R., and Schüepp, M.: 50 years of Alpine Weather Statistics (AWS), Meteorol. Zeitschrift, N.F. 7, 99-111, 1998.

Yienger, J. J., Klonecki, A. A., Levy II, H., Moxim, W. J., and Carmichael, G. R.: An evaluation of chemistry's role in the winter-spring ozone maximum found in the northern midlatitude free troposphere, J. Geophys. Res., 104(D3), 3655-3667, 1999.

Zanis, P., Monks, P. S., Schuepbach, E., Carpenter, L. J., Green, T. J., Mills, G. P., Bauguitte, S., and Penkett, S. A.: In-situ ozone production under free tropospheric conditions during FREETEX '98 in the Swiss Alps, J. Geophys. Res., 105(D19), $24223-$ 24234,2000 a.

Zanis, P., Monks, P. S., Schuepbach, E., and Penkett, S. A.: The role of in-situ photochemistry in the control of ozone during spring at the Jungfraujoch Observatory (3,580 m asl) - Comparison of model results with measurements, J. Atmos. Chem., 37, 1-27, $2000 \mathrm{~b}$.
Zanis, P., Monks, P. S., Green, T. J., Schuepbach, E., Carpenter, L. J., Mills, G. P., Richard, A., and Penkett, S. A.: Seasonal variation of peroxy radicals in the lower free troposphere based on observations from the FREE Tropospheric EXperiments at Jungfraujoch in the Swiss Alps, Geophys. Res. Lett., 30(10), 1497, doi:10.1029/2003GL017122, 2003.

Zellweger, C., Ammann, M., Buchmann, B., Hofer, P., Lugauer, M., Rüttimann, R., Streit, N., Weingartner, E., and Baltensperger, U.: Summertime $\mathrm{NO}_{\mathrm{y}}$ Speciation at the Jungfraujoch, $3580 \mathrm{~m}$ asl, Switzerland, J. Geophys. Res., 105(D5), 6655-6667, 2000.

Zellweger, C., Forrer, J., Hofer, P., Nyeki, S., Schwarzenbach, B., Weingartner, E., Ammann, M., and Baltensperger, U.: Partinioning of reactive nitrogen $\left(\mathrm{NO}_{y}\right)$ and dependence on meteorological conditions in the lower free troposphere, Atmos. Chem. Phys., 3, 770-796, 2003,

http://www.atmos-chem-phys.net/3/770/2003/. 